\title{
Uji Toksisitas Akut Yang Diukur Dengan Penentuan Ld50 Ekstrak Etanol Bunga Cengkeh (Syzygium aromaticum L.) Terhadap Mencit (Mus musculus) Menggunakan Metode Thompson-Weil
}

\author{
Moh A. Mustapa ${ }^{1}$ \\ Universitas Negeri Gorontalo \\ e-mail: mad.mustapa@gmail.com \\ Tety S. Tuloli ${ }^{2}$ \\ Universitas Negeri Gorontalo \\ Abdul Muis Mooduto ${ }^{3}$ \\ Universitas Negeri Gorontalo
}

\begin{abstract}
ABSTRAK
Cengkeh (Syzygium aromaticum) merupakan suatu tanaman yang sering digunakan oleh masyarakat sebagai rempah yang secara empiris dipercaya dapat meredakan sakit gigi. Secara ilmiah cengkeh berkhasiat sebagai antiseptik, antibakteri, antifungi, antiinflamasi, pencegahan kanker pereda stres umum, pembersih darah, gangguan pencernaan, pereda asma dan berbagai gangguan alergi. Dilakukan pengujian toksisitas bertujuan untuk menentukan nilai LD50 pada pemberian ekstrak etanol bunga cengkeh menggunakan metode thompson-weil serta pengaruhnya terhadap tingkah laku hewan. Hewan uji yang digunakan yaitu mencit putih jantan (Mus musculus) sebanyak 23 ekor dan terbagi menjadi 5 kelompok. Pemberian campuran ekstrak bunga cengkeh yaitu secara oral dengan dosis awal 0,21 mg/kgbb. Adapun pada uji toksisitas variasi dosis yang digunakan yaitu $0,47 \mathrm{~g} / \mathrm{kgbb}, 0,94 \mathrm{~g} / \mathrm{kgbb}, 1,89 \mathrm{~g} / \mathrm{kgbb}$ dan 3,78 $\mathrm{g} / \mathrm{kgbb}$ serta pemberian aquadest sebagai kelompok kontrol. Mencit diamati secara individu selama 24 jam setelah pemberian ekstrak dengan melihat jumlah hewan yang mati dan gejala toksik yang tampak. Dari hasil penelitian didapatkan mencit mati pada dosis 1,89 $\mathrm{g} / \mathrm{kgbb}$ sebanyak 3 dan pada dosis 3,78 $\mathrm{g} / \mathrm{kgbb}$ sebanyak 5 mencit sehingga nilai LD50 sebesar 1,75 g/kg.bb dan termasuk ke dalam kategori sedikit toksik. Pemberian bahan uji ektrak menimbulkan gejala toksik berupa aktifitas jantung menurun, kejang-kejang, terjadi penurunan aktifitas gerak, nafas melambat.
\end{abstract}

Kata kunci: Toksisitas Akut, Thompson-Weil, Bunga Cengkeh (Syzygium aromaticum)

\begin{abstract}
Clove (Syzygium aromaticum) is a plant that is often used by the community as a spice that is empirically believed to relieve toothache. Scientifically efficacious cloves as antiseptic, antibacterial, antifungal, anti-inflammatory, prevention of general stress relief cancer, blood cleanser, digestive disorders, asthma reliever and various allergic disorders. Conducted toxicity test aims to determine the value of LD50 in the extract of clove ethanol flower using thompson-weil method and its effect on animal behavior. The test animal used is male white mouse (Mus musculus) as much as 23 tail and is divided into 5 groups. Giving mixture of clove flower extract that is orally with initial dose 0,21 $\mathrm{mg} / \mathrm{kgbb}$. As for toxicity test, variation of dose used was $0,47 \mathrm{~g} / \mathrm{kgbb}, 0,94$ $\mathrm{g} / \mathrm{kgbb}, 1,89 \mathrm{~g} / \mathrm{kgbb}$ and 3,78 $\mathrm{g} / \mathrm{kgbb}$ and giving aquadest as control group. Mice were observed individually for 24 hours after administration of the extract by looking at the number of dead animals and visible toxic symptoms. From the result of the research, it was found that the mice died at the dose of $1.89 \mathrm{~g} / \mathrm{kgbb}$ of 3 and at the dose of $3.78 \mathrm{~g} / \mathrm{kgbb}$ for 5 mice so that the LD50 value of $1.75 \mathrm{~g} / \mathrm{kg} . \mathrm{bb}$ and included into the category slightly toxic. Provision of extract test materials cause toxic
\end{abstract}

Jurnal Frontiers Volume 1 Nomor 1, April 2018105

P-ISSN: 2621-0991 E-ISSN: 2621-1009 
symptoms such as decreased cardiac activity, convulsions, decreased activity of motion, slowing breath.

Keywords: Acute Toxicity, Thompson-Weil, Clove Flower (Syzygium aromaticum)

\section{PENDAHULUAN}

Plinius (Caius Plinius Secundus Sr.), berpendapat bahwa semua tumbuhan mempunyai daya pengobatan. Ditilik dari sudut keagamaan, penciptaan alam semesta maupun seisinya oleh Tuhan yaitu untuk memenuhi kepentingan dan keperluan manusia, misalnya sebagai makanan, bahan pengobatan dan lain-lain (Tjitrosoepomo, 2005). Data WHO menyebutkan sistem pengobatan secara tradisional masih melekat pada masyarakat yakni sekitar $80 \%$ dari penduduk dunia. Sejarah panjang menunjukan bahwa terdapat banyak praktik pengobatan secara tradisional berdasarkan pengalaman dan kemudian diteruskan dari generasi ke generasi, telah menunjukan keamanan dan kemanjuran obat tradisional. Namun, perlu adanya penelitian ilmiah untuk membuktikan kemanjuran dan keamanan dari obat tradisional tersebut (Muhtadi dkk, 2015).

Indonesia memiliki ekosistem alami dengan keanekaragaman hayati yang berlimpah, sehingga dimasukkan dalam kawasan alami dengan biodiversitas yang tinggi. Keanekaragaman hayati adalah penting bagi umat manusia karena menyediakan bahan baku untuk makanan, obat-obatan dan industri (Sutarno, 2015). Sebagian besar penggunaan obat di Indonesia masih diolah dengan metode tradisional dan masih berdasarkan resep yang bersifat adat-istiadat atau kebiasaan suatu masyarakat dan belum teruji secara ilmiah sehingga dosis pengobatan, efikasi, identifikasi, toksisitas, standarisasi dan regulasi produk herba masih diragukan. Penggunaan obat herbal menarik perhatian masyarakat baik kalangan akademisi ataupun profesional kesehatan (Utami, 2013) untuk mengetahui tingkat keamanan, manfaat dari penggunaan suatu tanaman yang berkhasiat obat.

Cengkeh (Syzygium aromaticum) merupakan suatu tanaman yang sering digunakan oleh masyarakat sebagai rempah dan banyak ditemukan di Indonesia sekitar $95 \%$ usaha rakyat dalam bentuk perkebunan yang tersebar diseluruh propinsi (Nurdjannah, 2004). Secara tradisional, cengkeh sejak lama digunakan sebagai bumbu masakan dan masyarakat percaya bahwa dengan mengigit sebutir bunga cengkeh kering dapat menyembuhkan sakit gigi dan terutama untuk menghilangkan bau mulut.

Secara ilmiah, cengkeh dimanfaatkan pada industri rokok, industri minuman, industri makanan, industri kosmetik, industri farmasi dan industri kimia lainnya (Towaha, 2012). Pada bidang industri farmasi, cengkeh termasuk jenis tanaman yang dapat dimanfaatkan sebagai obatobatan (Milind dan Deepa, 2011) dengan mempunyai segudang manfaat sebagai bahan obat seperti anestetik, obat rematik dan obat batuk (Wiryowidagdo, 2005), selain itu cengkeh juga berkhasiat sebagai antiseptik, antibakteri, antifungi, antiinflamasi, pencegahan kanker pereda stres umum, pembersih darah, gangguan pencernaan, kesehatan kardiovaskular (Bhowmik et al., 2012). Dikorea, cengkeh sering digunakan untuk penyakit asma dan berbagai gangguan alergi (Kim et al., 1998). Cengkeh banyak disenangi oleh masyarakat dikarenakan pada bunga, daun, dan batang cengkeh mengandung minyak cengkeh yang mempunyai aroma dan rasa khas (Nurdjannah, 2004). Adapun minyak 
cengkeh dapat diisolasi 1-4\% dari daun, 5$10 \%$ dari batang, dan $10-20 \%$ dari bunga cengkeh (Nurdjannah, 2004).

Berdasarkan kesepakatan yang ditetapkan oleh WHO suatu bahan/zat yang digunakan untuk tujuan pengobatan baik untuk manusia maupun hewan harus melalui tahap uji yaitu uji praklinik dan uji klinik. Peraturan Menteri Kesehatan RI Nomor $\quad 760 /$ menkes/per/IX/1992 menyatakan bahwa obat yang berasal dari tanaman harus dapat dibuktikan khasiat maupun keamanannya. Adapun uji praklinik adalah tahap uji yang tujuannya untuk mengetahui dan menetapkan tingkatan keamanan dan kebenaran khasiat dari suatu bahan/zat uji yang masih dalam dugaan, sehingga secara ilmiah dilakukan uji toksisitas dan uji aktivitas (Meles, 2010).

Uji toksisitas akut merupakan bagian dari uji praklinik yang dirancang untuk mengukur efek toksik suatu senyawa. Toksisitas akut mengacu pada efek toksik yang terjadi setelah pemberian oral dosis tunggal dalam selang waktu 24 jam. Dosis Letal tengah atau $\mathrm{LD}_{50}$ adalah tolak ukur statistik setelah pemberian dosis tunggal yang sering dipergunakan untuk menyatakan tingkatan dosis toksik sebagai data kuantitatif. Sedangkan gejala klinis, gejala fisiologis dan mekanisme toksik sebagai data kualitatifnya (Jenova, 2009).

Philippus Aureolus Theophratus Bombast von Hohenheim (1493-1541) menyatakan semua yang berkhasiat sebagai obat adalah racun, hanya dosis yang menjadikannya menjadi tidak beracun (Wirasuta, 2016). Begitu juga dengan tanaman cengkeh (Syzygium aromaticum), walaupun mempunyai segudang manfaat dan berkhasiat sebagai obat tentu mempunyai efek berbahaya ataupun efek kematian. Saat ini belum terdapat adanya laporan tentang tingkat keamanan dalam penggunaan cengkeh, oleh karena itu pentingya untuk dilakukan pengujian toksisitas terhadap cengkeh. Hal ini dikarenakan terdapat kandungan dari ekstrak bunga cengkeh yang berkemungkinan membahayakan bagi manusia jika dikonsumsi dengan dosis yang belum dianjurkan dan dalam penggunaan jangka panjang.

Metode Thompson-Weil menggunakan daftar perhitungan $\mathrm{LD}_{50}$ merupakan metode yang sering digunakan dalam penentuan tingkat ketoksikan suatu senyawa. Dipilih metode ini dikarenakan mempunyai tingkat kepercayaan yang cukup tinggi, hasil yang akurat, dan tidak memerlukan hewan coba yang cukup banyak.

Pentingnya mempelajari derajat efisiensi, keamanan dan berbagai macam efek yang ditimbulkan pada penggunaan ekstrak bunga cengkeh (Syzygium aromaticum) karena dapat memberikan informasi dan sebagai referensi untuk mempertimbangkan penggunaan tanaman cengkeh sebagai bahan berkhasiat obat sehingga nantinya dapat ditingkatkan statusnya sebagai obat herbal terstandar dan seterusnya.

Secara spesifik, belum ada jurnal ilmiah yang membahas mengenai toksisitas akut dari ekstrak bunga cengkeh. Namun beberapa data seperti pada jurnal penelitian oleh Francisco et al., (2014) mengatakan bahwa umumnya minyak essensial cengkeh sebagai zat yang aman apabila dikonsumsi dalam konsentrasi lebih rendah dari $1500 \mathrm{mg} / \mathrm{kg}$. Di sisi lain, Organisasi Kesehatan Dunia (WHO) menetapkan bahwa kuantitas harian diterima cengkeh per hari adalah 2,5 $\mathrm{mg} / \mathrm{kg}$ berat badan pada manusia. Selain itu, berdasarkan penelitian Parle Milind dan Khanna Deepa (2011) dengan judul "Pro-Cholinergic, Hypo-Cholesteromelic and Memory Improving Effect of Clove" bahwa serbuk cengkeh yang diberikan 
peroral tidak bersifat toksik dengan dosis $250 \mathrm{mg} / \mathrm{kg}$ dan $2000 \mathrm{mg} / \mathrm{kg}$ sehingga perlu adanya penelitian ilmiah lebih lanjut mengenai toksisitas dengan dosis berbeda.

Pada penelitian ini dilakukan uji toksisitas akut dengan sampel ekstrak tanaman cengkeh (Syzygium aromaticum) pada hewan coba yakni mencit yang diberikan secara peroral untuk mengetahui tingkat keamanan penggunaan tanaman cengkeh sebagai obat menggunakan metode thompson-weil.

\section{METODE}

Penelitian ini dilaksanakan di Laboratorium Bahan Alam dan Laboratoium Farmakologi dan Toksikologi, Jurusan Farmasi, Fakultas Olahraga dan Kesehatan, Universitas Negeri Gorontalo Jl. Jenderal Sudirman No. 6, Dulalowo Timur, Kota Tengah, Kota Gorontalo, Provinsi Gorontalo, yang dimulai dari bulan Januari 2017.

Penelitiani ini merupakan penelitian yang bersifat eksperimen yang bertujuan untuk melihat nilai $\mathrm{LD}_{50}$ ekstrak bunga cengkeh (Syzygium aromaticum) terhadap mencit menggunakan metode Thompson Weil.

Bunga cengkeh (Syzygium aromaticum) yang didapatkan dari desa sinombayuga, kecamatan posigadan, kabupaten bolaang mongondow selatan, sulawesi utara sudah dalam bentuk kering (telah selesai dijemur). Setelah itu diserbukan menggunakan blender.

Metode ekstraksi yang digunakan yaitu metode maserasi dimana serbuk simplisia cengkeh (Syzygium aromaticum) 400 gram dimasukkan kedalam wadah inert atau topless kaca kemudian dimasukkan pelarut etanol sebanyak 1000 $\mathrm{mL}$. Diaduk menggunakan stirrer dan sesekali dikocok. Diamkan selama 1-2 hari setelah itu, dipisahkan residu dan filtrat menggunakan kertas saring. Filtrat yang diperoleh dikumpulkan dan dipekatkan.

Hewan percobaan diaklimitasi terlebih dahulu selama 10 hari agar dapat menyesuaikan diri dengan lingkungan dan selama proses adaptasi mencit diberi makan jagung, wortel dan diberi minum dari ketimun. Mencit juga dipuasakan makan selama 8 jam namun tetap diberikan air sebelum dilakukan perlakuan.

Dosis yang digunakan berdasarkan penelitian Parle Milind dan Khanna Deepa (2011) terhadap serbuk cengkeh yang diberikan peroral tidak menyebabkan kematian pada dosis tertinggi yaitu 2000 $\mathrm{mg} / \mathrm{kg}$, p.o. kedua dosis $250 \mathrm{mg} / \mathrm{kg}$ dan $2000 \mathrm{mg} / \mathrm{kg}$ didapatkan tidak menimbulkan efek toksik. Pada uji pendahuluan, terlebih dahulu di uji dosis terendahnya yaitu $2000 \mathrm{mg} / \mathrm{kg}$.BB.

Mencit sebanyak 23 ekor dibagi menjadi lima kelompok perlakuan secara acak, yaitu satu kelompok kontrol yang diberikan dengan aquadest dan empat kelompok perlakuan yang diberikan dosis ekstrak sehingga masing masing kelompok hewan uji terdiri dari 5 ekor mencit jantan.

\begin{tabular}{ccc}
\multicolumn{2}{c}{ Tabel 1. Pembagian Kelompok Uji } \\
Pendahuluan \\
\hline Kelompok & $\begin{array}{c}\text { Jumlah } \\
\text { Mencit }\end{array}$ & Perlakuan \\
\hline Kontrol & 1 & Aquadest \\
\hline I & 2 & Diberi dosis I $(2 \mathrm{~g} / \mathrm{kg} / \mathrm{BB})$ \\
\hline II & 2 & Diberi dosis I $(6 \mathrm{~g} / \mathrm{kg} / \mathrm{BB})$ \\
\hline III & 2 & Diberi dosis I $(18 \mathrm{~g} / \mathrm{kg} / \mathrm{BB})$ \\
\hline IV & 2 & Diberi dosis I $(54 \mathrm{~g} / \mathrm{kg} / \mathrm{BB})$ \\
\hline
\end{tabular}

Tabel 2. Pembagian Kelompok

Perlakuan Uji Toksisitas

\begin{tabular}{ccc}
\hline Kelompok & $\begin{array}{c}\text { Jumlah } \\
\text { Mencit }\end{array}$ & Perlakuan \\
\hline Kontrol & 3 & Aquadest \\
\hline I & 5 & Diberi dosis I $(5 \mathrm{~g} / \mathrm{kg} / \mathrm{BB})$ \\
\hline II & 5 & Diberi dosis I $(8 \mathrm{~g} / \mathrm{kg} / \mathrm{BB})$ \\
\hline III & 5 & Diberi dosis I $(18 \mathrm{~g} / \mathrm{kg} / \mathrm{BB})$ \\
\hline IV & 5 & Diberi dosis I $(36 \mathrm{~g} / \mathrm{kg} / \mathrm{BB})$ \\
\hline
\end{tabular}

Pada uji toksisitas akut $\mathrm{LD}_{50}$ setiap kelompok perlakuan diberi ekstrak bunga 
cengkeh yang telah dilarutkan kedalam aquadest secara oral menggunakan sonde dengan tingkatan dosis yang berbeda yaitu 4 kelompok tingkatan dosis dan 1 kelompok kontrol. Mencit diamati selama 1-4 jam untuk melihat adanya gejala toksik yang tampak. Pengamatan dilakukan kembali pada 24 jam setelah pemberian dosis dengan menghitung jumlah mencit yang mati pada kelompok percobaan.

\section{Analisis Data}

Metode Penentuan Lethal Dose 50

Keterangan:

$$
\log \mathrm{m}=\log \mathrm{D}+\mathrm{d}(f+1)
$$

$\mathrm{m}=$ harga $\mathrm{LD}_{50}$

$\mathrm{D}=$ dosis terkecil yang digunakan

$\mathrm{d}=\log \mathrm{r}$ (kelipatan dosis)

$f=$ faktor

Rentang $\mathrm{LD}_{50}$ dapat ditentukan dengan:

Batas atas $\mathrm{LD}_{50} \quad=$ antilog $(\log \mathrm{m}+2$

$\delta \log \mathrm{m})$

Batas bawah $\mathrm{LD}_{50} \quad=\operatorname{antilog}(\log \mathrm{m}-2 \delta$

$\log \mathrm{m}$ )

$\delta \log \mathrm{m}=\mathrm{dx} \delta \mathrm{f}$

$\delta \mathrm{f} \quad=$ faktor dalam tabel biometrik

\section{HASIL DAN PEMBAHASAN}

\section{Rendemen Ekstrak Bunga Cengkeh}

Telah dilakukan ekstraksi bunga cengkeh (Syzygium aromaticum) dengan menggunakan metode maserasi dan diperoleh hasil rendemen sebagai berikut:

Tabel 3. Hasil Rendemen Ekstrak Bunga Cengkeh

\begin{tabular}{ccc}
\hline $\begin{array}{c}\text { Bobot } \\
\text { Simplisia }\end{array}$ & $\begin{array}{c}\text { Bobot } \\
\text { Ekstrak }\end{array}$ & \%Rendemen \\
\hline $400 \mathrm{~g}$ & $42 \mathrm{~g}$ & $10,5 \%$ \\
\hline
\end{tabular}

Proses ekstraksi dilakukan selama 24 jam dan sesekali dikocok dan diaduk menggunakan stirrer. Adapun simplisia yang diekstraksi yaitu sebanyak 400 gram dan mendapatkan bobot ekstrak kental sebesar 42 gram sehingga persen rendemen yang didapat yaitu sebesar $10,5 \%$. Adapun hasil persen rendemen yang didapat memenuhi syarat berdasarkan Dirjen POM (2000) dalam Vitasari (2013) bahwa hasil rendemen yang dipersyaratkan apabila proses ekstraksi berlangsung sempurna yaitu $10 \%-15 \%$.

Telah dilakukan uji penapisan fitokimia pada sampel bunga Cengkeh (Syzygium aromaticum) dan diperoleh hasilnya sebagai berikut:

Tabel 4. Hasil Uji Skrining Fitokimia

\begin{tabular}{|c|c|c|c|}
\hline $\begin{array}{c}\text { Senyawa } \\
\text { aktif }\end{array}$ & Cara Kerja & $\begin{array}{c}\text { Hasil } \\
\text { Uji }\end{array}$ & Ket \\
\hline Flavonoid & $\begin{array}{l}\text { Ekstrak } 0,5 \mathrm{~g} \text { dalam } \\
\text { cawan ditambahkan } 2 \\
\mathrm{~mL} \text { metanol kemudian } \\
\text { diaduk, ditambahkan } \\
\text { serbuk magnesium } 0,5 \mathrm{~g} \\
\text { dan } 3 \text { tetes } \mathrm{HCl} \text { pekat }\end{array}$ & $\begin{array}{l}\text { Warna } \\
\text { jingga }\end{array}$ & $\begin{array}{c}(+) \\
\text { Flavonoid }\end{array}$ \\
\hline Tanin & $\begin{array}{l}\text { Ekstrak } 0,5 \mathrm{~g} \text { dalam } \\
\text { cawan ditambahkan } 2 \\
\mathrm{~mL} \text { metanol kemudian } \\
\text { diaduk dan ditambahkan } \\
\mathrm{FeCl}_{3} \text { sebanyak } 3 \text { tetes }\end{array}$ & $\begin{array}{l}\text { Warna } \\
\text { merah }\end{array}$ & $\begin{array}{c}(-) \\
\text { Tanin }\end{array}$ \\
\hline
\end{tabular}

Skrining fitokimia dilakukan dengan cara memeriksa golongan senyawa kimia yang terdapat dalam ekstrak bunga Cengkeh. Hasil skrining fitokimia menunjukan bahwa ekstrak bunga cengkeh (Syzygium aromaticum) mengandung flavonoid. Hal ini dapat dilihat pada perubahan warna jingga yang berarti positif flavonoid. Berikut reaksi yang terjadi:

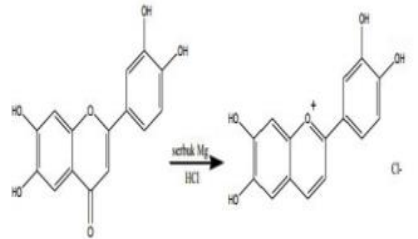

Pada uji ini, magnesium dan asam klorida bereaksi membentuk gelembunggelembung gas $\mathrm{H}_{2}$. Penambahan logam $\mathrm{Mg}$ dan $\mathrm{HCl}$ pekat berfungsi untuk mereduksi inti benzopiron yang terdapat pada struktur flavonoid sehingga terbentuk 
warna merah atau jingga. Jika didalam suatu ekstrak terdapat senyawa flavonoid akan terbentuk garam flavilium saat penambahan $\mathrm{Mg}$ dan $\mathrm{HCl}$ yang berwarna merah atau jingga (Setyowati, 2014). Penambahan $\mathrm{HCl}$ dalam uji kualitatif flavonoid berguna sebagai penghidrolisis flavonoid menjadi aglikonnya, yaitu dengan menghidrolisis O-glikosil. Glikosil akan tergantikan oleh $\mathrm{H}^{+}$dari asam, karena sifatnya yang elektrofilik. Glikosida berupa gula yang biasa dijumpai yaitu glukosa, galaktosa dan ramnosa. Serbuk Mg menghasilkan senyawa kompleks yang berwarna merah, kuning, maupun jingga (Marliana dkk, 2005).

\section{Hasil Uji Pendahuluan}

Tabel 5. Uji Pendahuluan

\begin{tabular}{ccccc}
\hline Kelompok & $\begin{array}{c}\text { Jumlah } \\
\text { Mencit }\end{array}$ & $\begin{array}{c}\text { Dosis } \\
\text { (g/kgbb) }\end{array}$ & $\begin{array}{c}\text { D. } \\
\text { Ekstrak } \\
\text { (g/kgbb) }\end{array}$ & Kematian \\
\hline Kontrol & 1 & Aquadest & - & 0 \\
\hline I & 2 & 2 & 0,21 & 0 \\
\hline II & 2 & 6 & 0,63 & 0 \\
\hline III & 2 & 18 & 1,89 & 1 \\
\hline IV & 2 & 54 & 5,67 & 2 \\
\hline
\end{tabular}

Telah dilakukan uji pendahuluan dengan penggunaan dosis terendah yaitu $2000 \mathrm{mg} / \mathrm{kgbb}$ dalam bentuk dosis serbuk sehingga untuk mendapatkan dosis dalam bentuk ekstrak maka dikalikan dengan persen rendemen $(10,5 \%)$ didapatkan hasil dosis ekstrak yaitu $0,21 \mathrm{mg} / \mathrm{kgbb}$. Untuk menentukan tingkatan dosis selanjutnya digunakan kelipatan dosis 3 .

Adapun hasil pada uji pendahuluan pada dosis kontrol yang diberikan Aquadest, dosis I, dan dosis II tidak menimbulkan kematian, pada dosis III terdapat 50\% kematian (1 mencit mati) sedangkan pada dosis IV terdapat $100 \%$ kematian (2 mencit mati).

\section{Hasil Uji Toksisitas}

Tabel 6. Uji Toksisitas Akut

\begin{tabular}{ccccc}
\hline Kelompok & $\begin{array}{c}\text { Jumlah } \\
\text { Mencit }\end{array}$ & $\begin{array}{c}\text { Dosis } \\
\text { (g/kgbb) }\end{array}$ & $\begin{array}{c}\text { D. } \\
\text { Ekstrak } \\
\text { (g/kgbb) }\end{array}$ & Kematian \\
\hline Kontrol & 3 & Aquadest & - & 0 \\
\hline I & 5 & 4,5 & 0,47 & 0 \\
\hline II & 5 & 9 & 0,94 & 0 \\
\hline III & 5 & 18 & 1,89 & 3 \\
\hline IV & 5 & 36 & 3,78 & 5 \\
\hline
\end{tabular}

Telah dilakukan uji toksisitas akut dengan jumlah mencit sebanyak 5 pada masing masing kelompok dan pada dosis kontrol dengan jumlah mencit 3. Pada dosis I dan II tidak terdapat kematian, pada dosis III terdapat $60 \%$ kematian dengan jumlah mencit yang mati sebanyak 3 sedangkan pada dosis IV terdapat $100 \%$ (semua mencit mengalami kematian) sehingga urutan kematiannya (r) yaitu $0,0,3,5$.

\section{Hasil Pengamatan Gejala Klinis}

Tabel 7. Gejala Klinis

\begin{tabular}{|c|c|c|}
\hline Dosis & Mencit & Gejala Klinis \\
\hline \multirow{5}{*}{ Dosis I } & Mencit 1 & \multirow{5}{*}{$\begin{array}{l}\text { Setelah pemberian bahan uji ekstrak } \\
\text { bunga cengkeh (Syzygium aromaticum) } \\
\text { mencit beraktifitas sebagaimana biasa } \\
\text { (normal) dan tidak terlihat adanya } \\
\text { gejala toksik. }\end{array}$} \\
\hline & Mencit 2 & \\
\hline & Mencit 3 & \\
\hline & Mencit 4 & \\
\hline & Mencit 5 & \\
\hline \multirow{5}{*}{ Dosis II } & Mencit 1 & $\begin{array}{l}\text { Mencit beraktifitas sebagaimana biasa, } \\
\text { tidak terlihat adanya tanda tanda toksik }\end{array}$ \\
\hline & Mencit 2 & Tremor \\
\hline & Mencit 3 & $\begin{array}{l}\text { Gelisah, detak jantung cepat, bulu } \\
\text { berdiri }\end{array}$ \\
\hline & Mencit 4 & Bingung, gelisah \\
\hline & Mencit 5 & $\begin{array}{l}\text { Mencit beraktifitas sebagaimana biasa, } \\
\text { tidak terlihat adanya tanda tanda toksik }\end{array}$ \\
\hline \multirow{5}{*}{$\begin{array}{c}\text { Dosis } \\
\text { III }\end{array}$} & Mencit 1 & $\begin{array}{l}\text { Gelisah, jantung berdebar kencang, } \\
\text { kaki belakang menjadi lumpuh dan } \\
\text { lemas }\end{array}$ \\
\hline & Mencit 2 & Jantung berdebar kencang \\
\hline & Mencit 3 & $\begin{array}{l}\text { Lemas, kaki belakang menjadi lumpuh } \\
\text { dan lemas }\end{array}$ \\
\hline & Mencit 4 & $\begin{array}{l}\text { Jantung berdebar kencang, keluar air } \\
\text { mata }\end{array}$ \\
\hline & Mencit 5 & Lemas, gelisah \\
\hline \multirow{5}{*}{$\begin{array}{l}\text { Dosis } \\
\text { IV }\end{array}$} & Mencit 1 & $\begin{array}{l}\text { Lemas, terjadi penurunan aktifitas, } \\
\text { nafas melambat, kaki belakang lumpuh }\end{array}$ \\
\hline & Mencit 2 & $\begin{array}{l}\text { Lemas dan terjadi penurunan aktifitas, } \\
\text { nafas setengah-setengah }\end{array}$ \\
\hline & Mencit 3 & $\begin{array}{l}\text { Lemas, terjadi penurunan aktifitas, } \\
\text { nafas melambat, kaki belakang lumpuh }\end{array}$ \\
\hline & Mencit 4 & $\begin{array}{l}\text { Lemas, terjadi penurunan aktifitas, } \\
\text { nafas melambat }\end{array}$ \\
\hline & Mencit 5 & $\begin{array}{l}\text { Lemas, terjadi penurunan aktifitas, } \\
\text { nafas setengah-setengah }\end{array}$ \\
\hline
\end{tabular}


Pada pengamatan gejala klinis dilakukan selama \pm 30 menit setelah pemberian dosis dan seterusnya selama 4 jam sampai 24 jam. Hewan menunjukkan gejala-gejala toksisitas pada sistem pernafasan, perubahan aktifitas, aktifitas jantung, kelumpuhan. Pengamatan yang dilakukan termasuk pada: kulit, bulu, mata, dan juga sistem saraf otonom, sistem saraf pusat, aktivitas somatomotor serta tingkah laku. Selain itu, perlu juga pengamatan pada kondisi: gemetar, kejang, salivasi, diare, lemas, tidur dan koma. Adapun mencit yang mati berada pada dosis III dengan mencit 1,3,4 sedangkan pada dosis IV semua mencit mengalami kematian.

Pada penelitian ini menggunakan sampel uji bunga cengkeh (Syzygium aromaticum) yang diperoleh dari Desa Sinombayuga, Kecamatan Posigadan, Kabupaten Bolaang-Mongondow Selatan yang sudah dikeringkan selama 2-3 hari. Sampel bunga cengkeh kering tersebut diserbukkan dengan menggunakan blender. Tujuan diserbukkan yaitu agar permukaan dari bunga cengkeh menjadi lebih luas sehingga senyawa yang terkandung didalamnya dapat terekstraksi sempurna. Sampel diuji penapisan fitokimia untuk mengetahui kandungan yang terdapat didalamnya. Pada uji flavonoid, ekstrak kental dilarutkan dengan alkohol kemudian ditambahkan $\mathrm{Mg}$ dan $\mathrm{HCl}$ masing-masing sebanyak 2 tetes dan dikocok, dibiarkan sampai terjadi perubahan warna. Adapun reaksi warna yang terjadi berupa warna jingga, sehingga dapat dikatakan positif (+) flavonoid. Penambahan logam $\mathrm{Mg}$ dan $\mathrm{HCl}$ pekat berfungsi untuk mereduksi inti benzopiron yang terdapat pada struktur flavonoid sehingga terbentuk warna merah atau jingga (Setyowati, 2014).

Kemudian sampel uji tersebut diekstraksi untuk mendapatkan atau menarik kandungan kimia yang terdapat pada serbuk bunga cengkeh. Metode ekstraksi yang digunakan adalah metode maserasi dengan cairan penyari yaitu Etanol 70\%. Metode maserasi dipilih dikarenakan metode ini menggunakan peralatan yang sederhana sehingga mudah dilakukan (Depkes RI, 2000) menghasilkan rendemen yang cukup tinggi (Sundari, 2010). Adapun proses maserasi dari serbuk bunga cengkeh dilakukan dengan cara merendam simplisia dalam cairan penyari dan beberapa kali dilakukan pengadukan atau pengocokan untuk mempercepat proses penyarian. Proses ekstraksi ini dilakukan selama 24 jam karena semakin lama waktu ekstraksi, kesempatan untuk bersentuhan semakin besar sehingga hasilnya juga bertambah sampai titik jenuh larutan. Proses ekstraksi tidak menggunakan cara panas seperti refluks atau panas dingin seperti soklet karena dikhawatirkan ada golongan senyawa yang tidak tahan terhadap pemanasan seperti flavonoid yang mudah teroksidasi pada suhu tinggi (Koirewoa, 2012). Menurut Sundari (2010) kemungkinan rusaknya senyawa kimia yang terkandung di dalam suatu bahan alam dapat dihindari karena tidak disertai pemberian panas.

Setelah 24 jam dilakukan perendaman terhadap serbuk bunga cengkeh (Syzygium aromaticum), dilakukan penyaringan untuk memperoleh filtratnya sedangkan sisa ampas diremaserasi dengan menggunakan pelarut yang sama. Proses remaserasi dilakukan untuk mendapatkan filtrat yang warnanya sedikit pucat dari filtrat sebelumnya, hal ini menandakan bahwa simplisia terekstraksi maksimal. untuk meningkatkan keefektifan penyarian, maka digunakan campuran pelarut yang berlainan seperti etanol dan air. Etanol $70 \%$ sangat efektif dimana bahan pengganggu hanya skala kecil yang 
turut kedalam cairan pengekstraksi sehingga menghasilkan jumlah bahan aktif yang optimal (Voight, 1994). Selain itu etanol $70 \%$ digunakan sebagai cairan penyari karena mempunyai keuntungan seperti aman dan tidak bersifat toksik. Pelarut etanol $70 \%$ bersifat polar karena terdiri dari campuran air dan etanol sehingga senyawa ada yang tertarik oleh etanol dan ada yang tertarik air. Etanol merupakan pelarut serba guna yang sangat baik untuk ekstraksi pendahuluan karena dapat mengekstraksi senyawa polar dan nonpolar (Harborne, 1987).

Filtrat yang diperoleh dari hasil ekstraksi kemudian diuapkan untuk menghilangkan pelarut yang ada pada filtrat bunga cengkeh (Syzygium aromaticum) sehingga mendapatkan ekstrak yang kental dan pekat. Ekstrak kental yang diperoleh ditimbang kemudian dibandingkan bobotnya dengan bobot simplisia awal. Adapun persen perbandingan antara bobot ekstrak yang dihasilkan dengan bobot simplisia awal menyatakan nilai rendemen. Dari 400 gram serbuk bunga cengkeh (Syzygium aromaticum) yang dimaserasi, didapatkan ektrak kental sebesar 42 gram sehingga hasil perhitungan rendemen ekstrak bunga cengkeh (Syzygium aromaticum) didapatkan hasil sebesar 10,5\%. Persentase ini masuk dalam range persen rendemen yang dipersyaratkan yakni 10\%$15 \%$ yang menunjukkan bahwa proses ekstraksi berlangsung sempurna (Dirjen POM, 2000) dalam Vitasari (2013). Hasil rendemen yang diperoleh dapat digunakan untuk menentukan dosis yang akan digunakan pada uji toksisitas akut.

Pada penelitian ini hewan percobaan yang digunakan yaitu mencit putih jantan (Mus musculus). Mencit dipilih karena mempertimbangkan ukurannya yang kecil, mudah dalam pemeliharaan dan perawatan. Mencit jantan tidak dipengaruhi siklus estrus yang dapat menimbulkan aktivitas hormon yang tidak stabil yang nantinya akan berpengaruh pada proses pengamatan (Lu, 1995).

Mencit yang digunakan terlebih dahulu diaklimitasi selama 10 hari pada suhu ruangan agar mencit dapat beradaptasi dengan lingkungan barunya. Setiap harinya kandang mencit dibersihkan dan diganti sekamnya. Selain itu, mencit diberi makan jagung dan minum (ad libitium) sehari 2 kali yaitu pagi dan sore. Kriteria mencit yang digunakan yaitu mencit dewasa dengan kisaran umur 2-3 bulan dan memeliki berat 20-30 gram.

Pada pengujian ini pemberian dilakukan secara oral dengan menggunakan sonde. Rute ini disesuaikan dengan kebiasaan masyarakat dalam mengonsumsi bunga cengkeh (Syzygium aromaticum). Dalam penetapan dosis, terlebih dahulu dilakukan uji pendahuluan pada dosis serbuk $2000 \mathrm{mg} / \mathrm{kg}$. Dosis yang digunakan berdasarkan penelitian sebelumnya bahwa serbuk bunga cengkeh yang diberikan peroral tidak menyebabkan efek toksik pada dosis tertinggi yaitu 2000 $\mathrm{mg} / \mathrm{kg}$ (Milind dan Deepa, 2011). Namun, dosis $2000 \mathrm{mg} / \mathrm{kg}$ tersebut masih dalam bentuk serbuk sehingga terlebih dahulu dikonversi dalam dosis ekstrak dan didapatkan dosisnya $0,21 \mathrm{~g} / \mathrm{kgbb}$.

Setelah mencit diaklimitasi, dipilih mencit sebanyak 23 ekor yang memenuhi kriteria berat 20-30 gram kemudian dibagi menjadi lima kelompok perlakuan dan setiap kelompok mempunyai rata-rata berat yang hampir sama. Adapun pada kelompok pertama yaitu sebanyak 3 mencit diberikan aquadest sebagai kelompok kontrol dan empat kelompok tingkatan dosis yang masing-masing sebanyak 5 mencit diberikan ekstrak bunga cengkeh (Syzygium aromaticum) yang dilarutkan menggunakan aquadest. 
Sebelum dilakukan uji toksisitas, terlebih dahulu dilakukan uji pendahuluan dengan mengelompokkan mencit menjadi 4 kelompok yang masing-masing kelompok terdiri dari 2 mencit. Adapun pada kelompok I diberikan dosis 0,21 $\mathrm{g} / \mathrm{kgbb}$ dengan kelipatan dosisnya sebesar 3 sehingga dosis pada kelompok II, III, IV masing-masing adalah 0,63 g/kgbb, 1,89 $\mathrm{g} / \mathrm{kgbb}$, dan 5,67 g/kgbb. Hasil yang diperoleh dari uji pendahuluan yaitu; pada Dosis I tidak terdapat kematian (0\%), dosis II $0 \%$, dosis III $50 \%$ (dengan 1 mencit mati), dan dosis IV $100 \%$ (2 mencit mati).

Dari hasil uji pendahuluan, rentan dosis yang akan digunakan pada uji toksisitas adalah 0,4 $\mathrm{g} / \mathrm{kgbb}$ sampai 4,3 g/kgbb. Maka diambil keputusan penggunaan dosis terendah yaitu sebesar $0,47 \mathrm{~g} / \mathrm{kgbb}$ sedangkan untuk dosis selanjutnya ditentukan dengan menggunakan kelipatan 2, sehingga didapatkan tingkatan dosis selanjutnya yaitu $0,94 \mathrm{~g} / \mathrm{kgbb}, 1,89 \mathrm{~g} / \mathrm{kgbb}$ dan 3,78 $\mathrm{g} / \mathrm{kgbb}$.

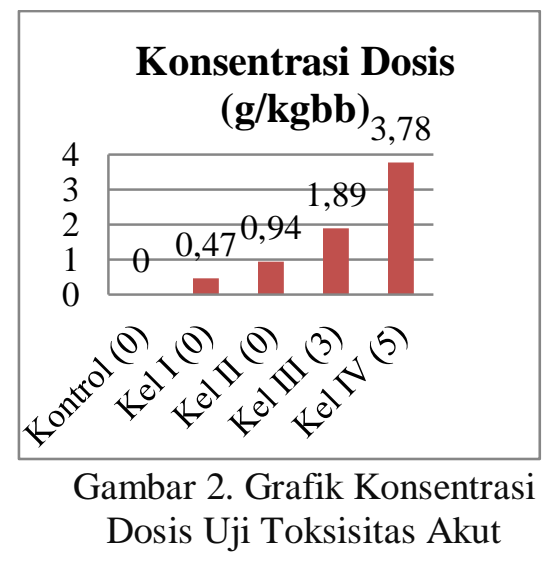

Diperoleh hasil dari uji toksisitas yaitu pada kelompok I setelah pemberian ekstrak bunga cengkeh (Syzygium aromaticum) tidak terdapat kematian dan mencit beraktifitas sebagaimana biasa. Dari hasil ini dapat disimpulkan bahwa dosis $0,47 \mathrm{~g} / \mathrm{kgbb}$ tidak toksik ataupun tidak menimbulkan gejala toksik.

Pada kelompok II diberikan dosis 0,94 $\mathrm{g} / \mathrm{kgbb}$ tidak terdapat mencit yang mati, namun diperoleh hasil pengamatan klinis yaitu pada mencit 1 setelah diberikan ekstrak bunga cengkeh (Syzigium aromaticum) dengan volume pemberian 0,71 mL tidak terdapat gejala toksik dan mencit beraktifitas sebagaimana biasa. Mencit 2 dengan volume pemberian 0,70 $\mathrm{mL}$ terjadi tremor pada beberapa detik setelah pemberian ekstrak yang ditandai dengan otot berkedut dan menunjukan gerakan kulit yang cepat (OECD, 2000). Sejantunya pada mencit 3 dengan volume pemberian $0,69 \mathrm{~mL}$ memperlihatkan tanda-tanda gejala klinis seperti gelisah, detak jantung cepat, bulu berdiri. Gejala seperti detak jantung cepat dapat disebabkan mencit panik/cemas segera setelah diberikan perlakuan sehingga gejala ini belum dapat disimpulkan sebagai akibat dari pemberian ekstrak bunga cengkeh (Syzygium aromaticum) selain itu, 5 menit setelah pemberian ekstrak bunga cengkeh (Syzygium aromaticum) mencit kembali beraktifitas sebagaimana biasa. Mencit 4 dengan volume pemberian $0,68 \mathrm{~mL}$ tercatat beberapa gejala klinis yang sama seperti pada mencit 3 seperti bingung dan gelisah namun 5 menit setelah pemberian ekstrak bunga cengkeh (Syzygium aromaticum) mencit beraktifitas sebagaimana biasa. Pada mencit 5 dengan volume pemberian $0,68 \mathrm{~mL}$ tidak memperlihatkan adanya gejala toksik serta beraktifitas sebagaimana biasa.

Pada kelompok III diberikan dosis $1,89 \mathrm{~g} / \mathrm{kgbb}$ mulai terliihat adanya tandatanda kematian mencit. Pada mencit 1 dengan volume pemberian $0,80 \mathrm{~mL}$ terlihat gelisah segera setelah diberikan ekstrak bunga cengkeh (Syzygium aromaticum). Pada menit ke 9 mulai 
terlihat ketidaknormalan seperti jantung berdebar kencang serta kaki belakang menjadi lemas dan sedikit lumpuh. Kemungkinan penyebab kelumpuhan pada kaki mencit ini yaitu berhubungan dengan sistem saraf yang mengendalikan gerakan mengalami kerusakan sehingga terjadi kegagalan saat mengendalikan otot-otot pada kaki. Tercatat pada menit ke 24 mencit mengalami kematian sehingga dapat disimpulkan dosis $1,89 \mathrm{~g} / \mathrm{kgbb}$ sudah dapat menimbulkan efek kematian, namun masih dilihat pada mencit yang selanjutnya. Pada mencit 2 dengan volume pemberian $0,80 \mathrm{~mL}$ tidak mengalami kematian, hanya saja terjadi gejala berupa jantung yang berdebar kencang namun setelah beberapa menit mencit beraktifitas sebagaimana biasa. Pada mencit 3 dengan volume pemberian $0,73 \mathrm{~mL}$ mengalami lemas, kaki belakang menjadi lumpuh dan lemas. Gejala ini bisa terjadi karena adanya gangguan pada sistem saraf yang mengendalikan gerakan seperti tangan dan kaki mengalami kegagalan dalam mengendalikan otot-otot sehingga mencit menjadi lumpuh. Setelah 10 menit mengalami kelumpuhan dan kurangnya aktifitas, mencit 3 mengalami kematian sehingga dapat disimpulkan kematian mencit diakibatkan pemberian ekstrak bunga cengkeh (Syzygium aromaticum). Pada cengkeh terdapat kandungan flavonoid sehingga dapat diperkirakan menjadi penyebab mengganggu sistem saraf. Menurut Sandhar (2011), flavonoid mempunyai cara kerja mengganggu sistem saraf. Pada mencit 4 dengan volume pemberian $0,73 \mathrm{~mL}$ mengalami kematian pada 30 menit setelah pemberian ekstrak namun sebelum mencit mati tercatat terjadi gejala toksik berupa kejang-kejang dan jantung berdebar kencang. Konvulsi atau kejang-kejang ditandai dengan otot tubuh mengalami fluktuasi konstraksi dan peregangan dengan sangat cepat sehingga menyebabkan gerakan mencit yang tidak terkendali. Hal ini dikarenakan dosis yang sudah dikategorikan mempunyai efek toksik. Pada mencit 5 dengan volume pemberian $0,73 \mathrm{~mL}$ mencit tidak mengalami kematian namun mengalami gelisah serta terjadi gejala toksik awal seperti lemas. Setelah 15 menit setelah pemberian ekstrak bunga cengkeh (Syzygium aromaticum) mencit beraktivitas sebagaimana biasa.

Pada kelompok IV dengan dosis 3,78 $\mathrm{g} / \mathrm{kgbb}$ dengan rata-rata volume pemberian sebanyak $0,86 \mathrm{~mL}$ semua mencit mengalami kematian dengan beberapa gejala toksik seperti pada mencit 1 lemas, terjadi penurunan aktifitas, nafas melambat. Mencit 2 terjadi gejala toksik seperti lemas, terjadi penurunan aktifitas, nafas setengah-setengah. Mencit 3 terjadi gejala toksik berupa lemas, terjadi penurunan aktifitas dan nafas melambat. Mencit 4 juga terlihat beberapa gejala toksik seperti lemas, terjadi penurunan aktifitas, nafas melambat dan pada mencit 5 juga terjadi gejala toksik seperti nafas melambat, terjadi penurunan aktifitas dan nafas setengah-setengah. Semua mencit mengalami kematian pada menit 10-30 menit setelah pemberian ekstrak sehingga dapat disimpulkan dosis IV merupakan dosis yang berbahaya karena dapat membunuh mencit dalam kurung waktu yang cepat.

Menurut Marlinda dkk (2012), senyawa aktif yang terdapat dalam tanaman obat hampir selalu toksik apabila diberikan dalam dosis tinggi. Semua keracunan terjadi akibat reaksi antara zat beracun dengan reseptor dalam tubuh (Katzung, 2002). Pemberian oral ekstrak etanol bunga cengkeh menyebabkan zat aktif yang terdapat dalam ekstrak bunga cengkeh terabsorbsi dalam saluran pencernaan kemudian mengalami proses distribusi dan metabolisme. Produk 
metabolisme yang bersifat toksik bekerja sebagai inhibitor enzim untuk tahap metabolisme selanjutnya. Reaksi antara zat aktif dengan reseptor dalam organ efektor menyebabkan timbulnya gejala keracunan (Donatus, 1998).

Dari hasil pengamatan dapat disimpulkan bahwa pada dosis I mencit tidak mengalami kematian (0\%), pada dosis II $(0 \%)$ pada dosis III mengalami kematian sebanyak 3 mencit dari jumlah mencit sebanyak 5 dengan persentase kematian $60 \%$ sedangkan pada dosis IV semua mencit mengalami kematian sehingga persentase kematian yaitu $100 \%$ sehingga urutan kematian pada uji toksisitas akut yaitu 0,0,3,5. Berdasarkan tabel weil harga $\mathrm{r} 0,0,3,5$ mempunyai nilai $\mathrm{f}$ (factor) yaitu 0,90000. Kemudian dianalisis data kematian berdasarkan tabel weil sehingga nilai $\mathrm{LD}_{50}$ dari ekstrak bunga Cengkeh (Syzygium aromaticum) didapatkan $\quad 1,75 \quad$ g/kg.bb dimana berdasarkan derajat ketoksikan termasuk pada kategori sedikit toksik dengan nilai rentang $\mathrm{LD}_{50}$ yaitu sebesar $1,2 \mathrm{~g} / \mathrm{kgbb}-$ $2,4 \mathrm{~g} / \mathrm{kgbb}$ (Thompson and Weil, 1952).

\section{PENUTUP}

\section{Kesimpulan}

Nilai $\mathrm{LD}_{50}$ hasil pengujian toksisitas akut ekstrak bunga Cengkeh (Syzygium aromaticum) sebesar $1,75 \mathrm{~g} / \mathrm{kg} . \mathrm{bb}$ dan termasuk ke dalam kategori sedikit toksik. Pemberian bahan uji ektrak menimbulkan gejala toksik berupa aktifitas jantung menurun, kejang-kejang, terjadi penurunan aktifitas gerak, nafas melambat, tremor.

\section{DAFTAR PUSTAKA}

Bhowmik D, dkk. (2012). Journal of Pharmacolognosy and Phytochemistry: Recent Trend in Indian Tradisional Herbs Syzygium Aromaticum and its Health Benefits. Department of Pharmaceutical
Sciences, Karpagam University: India.

Departemen Kesehatan RI, (1979). Farmakope Indonesia Edisi III. Direktorat Jendral Pengawas Obat dan Makanan: Jakarta.

Departemen Kesehatan RI, (1999). Cara Pengelolaan Simplisia Yang Baik. Direktorat Jendral Pengawasan Obat dan Makanan: Jakarta.

Departemen Kesehatan RI. (2000). Parameter Standar Umum Ekstrak Tumbuhan Obat. Derektorat Jendral Pengawasan Obat dan Makanan: Jakarta.

Departemen Kesehatan RI, (2000). Pedoman Pelaksanaan Uji Klinik Obat Tradisional. Direktorat Pengawasan Obat Tradisional: Jakarta.

Donatus I.A., (1998). Toksikologi Dasar. Fakultas Farmasi, Universitas Gadjah Mada: Yogyakarta.

Harborne, J. B. (1987). Metode Fitokimia, Penuntun Cara Modern Menganalisis Tumbuhan. Terjemahan K. Padmawinata dan I. Soediro. ITB, Bandung.

Katzung BG. (2002). Farmakologi Dasar dan Klinik. Sjabana D, Isbadianti SE, Basori A, Soedjak NM, uno I, Rhamadani, Zakaria PS, penerjemah dan penyunting. Jakarta Salemba Medika. Terjemahan dari: Basic dan Clinical Pharmacology Ed ke-8.

Kim, H. M., Lee, E. H., Hong, S. H., Song, H. J., Shin, M. K., Kim, S. H., \& Shin, T. Y. (1998). Effect of 
Syzygium aromaticum extract on immediate hypersensitivity in rats. Journal of Ethnopharmacology. Wonkwang University and Woosuk University: South Korea.

Koirewoa Y. A, Fatimawali, Wiyono W. I,, (2012). Isolasi Dan Identifikasi Senyawa Flavonoid Dalam Daun Beluntas (Pluchea Indica L.). Program Studi Farmasi FMIPA UNSRAT: Manado.

Lu, F C., (1995). Toksikologi Dasar Asas, Organ Sasaran dan Penilaian Risiko, (Alih bahasa: Edi Nugroho). Edisi kedua. UI Press: Jakarta.

Marliana, S.D, Suryanti, V, dan Suyono. (2005). Skrining Fitokimia dan Analisis Kromatografi Lapis Tipis Komponen Kimia Buah Labu Siam ( Sechium edule Jacq.Swartz.) dalam Ekstrak Etanol. Biofarmasi 2(1) 26 31, Februari 2005, ISSN: 1693-2242. Jurusan Biologi FMIPA UNS Surakarta.

Marlinda M, Sangi MS, Wuntu AD. (2012). Analisis senyawa metabolit sekunder dan uji toksisitas ekstrak etanol biji buah alpukat (Persea americana Mill). Jurnal MIPA UNSRAT.

Meles K.D, (2010). Peran Uji Praklinik Dalam Bidang Farmakologi. Pusat Penerbitan dan Percetakan Unair (AUP). Perpustakaan Universitas Airlangga: Surabaya.

Milind Parle and Deepa Khanna, (2011). Pro-Cholinergic, HypoCholesterolemic and Memory Improving Effect of Clove. Guru
Jambheshwar University of Science and Tehcnology: India.

Muhtadi, Andi Suhendi, Agus Triyono dan Agus Ulinuha, (2015). Introduksi Teknologi Tepat Guna Untuk Perbaikan Proses Produksi Dan Pengembangan Usaha Jamu Herbal Di Cv. Arba'in Jaya Mandiri Surakarta. Fakultas Farmasi, Universitas Muhammadiyah Surakarta: Surakarta.

Nurdjannah, Nanan. (2004). Diversifikasi Penggunaan Cengkeh. Balai Besar Penelitian dan Pengembangan Pasca Panen Pertanian Indonesian Center for Agricultural Postharvest Research and Development: Bogor.

Setyowati dkk, (2014). Skrining Fitokimia dan Identifikasi Komponen Utama Ekstrak Metanol Kulit Durian (Durio zibethinur Murr.) Varietas Petruk. Kimia Organik Bahan Alam. Prodi Pendidikan Kimia, Fakultas Keguruan dan Ilmu Pendidikan. Universitas Sebelas Maret Surakarta: Indonesia.

Sandhar Harleen Kaur, Bimlesh Kumar, Sunil Prasher, Prashant Tiwari, Manoj Salhan, Pardeep Sharma, (2011). A Review of Phytochemistry and Pharmacology of Flavonoids. International Pharmaceutic Sciencia. Lovely School of Pharmaceutical Sciences, Lovely Professional University, Jalandhar-Delhi G.T. Road (NH-1), Phagwara. Punjab: India.

Sundari Ida, (2010). Identifikasi Senyawa Dalam Ekstrak Etanol Biji Buah Merah (Pandanus Conoideus Lamk.). Skripsi. Fakultas Matematika Dan 
Ilmu Pengetahuan Alam Universitas Sebelas Maret Surakarta: Surakarta.

Sutarno, (2015). Biodiversitas Indonesia: Penurunan dan upaya pengelolaan untuk menjamin kemandirian bangsa. Jurusan Biologi, FMIPA, Universitas Sebelas Maret. Surakarta.

Thompson dan Weil CS. (1952). Tables for Convenient Calculation of Median EffectiveDose (LD50 or ED50) And Instructions in Their Use. Biometrics 8:249-263.

Tjitrosoepomo, (2005). Taksonomi Tumbuhan Obat-Obatan. Universitas Gadjah Mada Press: Yogyakarta.

Towaha J. (2012). Manfaat Eugenol Cengkeh dalam Berbagai Industri Di Indonesia. Balai Penelitian Tanaman Industri dan Penyegar: Jawa Barat.

Utami dan Puspaningtyas, (2013). The Miracle of Herbs. PT Agromedia Pustaka: Jakarta.

Vitasari, E W. (2013). Antihiperlipidemia Ekstrak Etanol Batang Kayu Kuning (Arcangelisia flafa (L.) Merr.) Terhadap Tius Putih Galur Wistar Yang Diinduksi Pakan Tinggi Lemak. Skripsi. Sekolah Tinggi Ilmu Farmasi "Yayasan Farmasi". Semarang.

Voight, T. (1994). Pelajaran Teknologi Farmasi. Gadjah Mada University Press: Fakultas Farmasi, Universitas Gadjah Mada: Yogyakarta.

Wirasuta I Made Agus G dan Niruri Rasmaya, (2016). Toksikologi Umum. Buku Ajar. Jurusan Farmasi Fakultas Matematika Dan Ilmu Pengetahuan Alam: Universitas Udayana.
Wiryowidagdo, (2005). Kimia \& Farmakologi Bahan Alam Edisi 2. Buku Kedokteran EGC: Jakarta. 